\title{
Article \\ Satisfaction of E-Learners with Electronic Learning Service Quality Using the SERVQUAL Model
}

\author{
Razia Sultana Sumi ${ }^{1}$ and Golam Kabir ${ }^{2, *}$ D \\ 1 Department of Marketing, Jagannath University, Dhaka 1100, Bangladesh; razia6du@gmail.com \\ 2 Industrial Systems Engineering, University of Regina, Regina, SK S4S 0A2, Canada \\ * Correspondence: golam.kabir@uregina.ca
}

check for

updates

Citation: Sumi, R.S.; Kabir, G. Satisfaction of E-Learners with Electronic Learning Service Quality Using the SERVQUAL Model. J. Open Innov. Technol. Mark. Complex. 2021, 7, 227. https://doi.org/10.3390/ joitmc7040227

Received: 30 August 2021

Accepted: 5 November 2021

Published: 9 November 2021

Publisher's Note: MDPI stays neutral with regard to jurisdictional claims in published maps and institutional affiliations.

Copyright: (c) 2021 by the authors. Licensee MDPI, Basel, Switzerland. This article is an open access article distributed under the terms and conditions of the Creative Commons Attribution (CC BY) license (https:// creativecommons.org/licenses/by/ $4.0 /)$.

\begin{abstract}
Electronic learning (E-learning) is an innovative learning tool that provides an opportunity for technology-driven distance teaching. E-learning not only enhances learning quality, but it has also become the only medium of learning during the COVID-19 pandemic, when people have been forced to stay at home. Due to the pandemic, most countries have initiated online learning to continue the learning process, thus lessening the study gap. Against this backdrop, it is imperative to explore the perception and satisfaction level of e-learners regarding e-learning tools. In this study, a quantitative approach was conducted on the students of two leading public universities (graduates and postgraduates) to identify the impact of the determinants of the SERVQUAL model (reliability, responsiveness, assurance, empathy, and website design), as well as 'learning content', on overall perceived quality and satisfaction. In total, 895 respondents participated in the study, and data were analyzed with Amos 23 to confirm the hypotheses, utilizing structural equation modeling. The findings reveal that all the variables of the measurement model had a significant effect on perceived service quality and thus user satisfaction except for responsibility. The results make a significant contribution to those decision-makers and university authorities attempting to ensure e-learners' satisfaction.
\end{abstract}

Keywords: e-learning; perceived service quality; satisfaction; SERVQUAL; COVID-19 pandemic

\section{Introduction}

The rapid growth of electronic products and internet systems has made the world smaller, and we now live in an e-world. Electronic learning (E-learning) is one of the revolutionary innovations of this e-world. E-learning is a teaching and learning approach based on the use of electronic media and devices as tools to improve access for communication, interaction, and training, and it enables the implementation of innovative ways of understanding and developing learning [1]. It works in educational environments, training program initiatives, or for skill development purposes. Digital innovation and advanced information communication technology (ICT) facilities have opened a new dimension of learning in an educational environment whereby effective communication has been developed between students and instructors on online platforms. In this changing environment, e-learning has not only become popular with high-school students [1,2] but also become an effective learning tool for college and university students in many countries [3-5].

During the COVID-19 pandemic, the contribution of information technology has gained momentum, and the education sector is no exception. From 2020 onward, the outbreak of COVID-19 forced lockdowns across the globe. A particularly infectious disease, it changed the conventional life across the entire world; the problem of spreading infection due to close contact led to considerable societal problems [6]. This has pressured policymakers to consider alternative teaching methods. Therefore, learners across all countries adopted e-learning methods during the lockdown. Numerous countries have begun an online education framework and are continuing with this concept to limit the learning gap 
that arises due to pandemics [7]. Higher educational institutions have introduced virtual learning systems to overcome the interruption gap of study and learning actions [8]. In a study in India, Khan et al. [9] found that e-learning has gained immense popularity among students due to the ability to interact with educators and each other during the pandemic. The Bangladesh government has also taken several initiatives to help the instructive foundations through blended learning to enhance competitiveness and reduce the study gap in this lockdown. At present, e-learning has become a substitute for conventional face-to-face classroom methods at all levels, primary to university. A high percentage of educators $(79.8 \%)$ in Bangladesh consider it essential to continue the online learning process to reduce the education gap [10]. In Bangladesh, computer-assisted teaching technologies are considered as open innovation dynamics to continue the pace of e-learning. However, the initiative of distance learning is facing certain challenges, such as lack of adaptability with online platform learning, disruptive internet facilities in rural areas and technical problems, and the crisis of computer and smartphone management [11]. In addition to academic institutional education, skill-development-based e-learning platforms are doing well in Bangladesh.

E-learning guarantees a creative cycle to improve ability, information, and quality learning through students' electronic interaction [12]. The increased participation of students in e-learning may lead to their knowledge and interest being enriched $[13,14]$. To oversee e-learning conveyance, it is important that the nature of e-learning is evaluated precisely [15] and that work is done with e-learning suppliers to customize their products to address student issues. Against such a background, it is relevant to examine the perception of students regarding the internet learning framework utilized at college and university level during the COVID-19 pandemic. To ensure value-added, goal-oriented e-education, it is important to have the ability to evaluate the quality of the e-learning process. The recent wave of e-learning necessitates a metric evaluation of service quality to measure the actual perception students have of it. The SERVQUAL model is a widely used instrument to measure service quality and is applied in this study to measure e-learning service quality.

The purpose of this study is to measure the relationship between the predictors of the SERVQUAL model and the perceived service quality, which indicates student satisfaction toward distance learning - a new teaching tool for Bangladeshi students. A model was proposed on the basis of existing literature and measurement instruments to evaluate the effectiveness of e-learning. Evaluating this model, specifically focusing on extending the SERVQUAL model to adopt 'learning content', provides valuable insight into the proposed dimensions to evaluate the quality of e-learning during this pandemic and future ones. More specifically, this study aims to:

(1) Examine the impact of the SERVQUAL instruments on perceived e-learning quality

(2) Assess the relationship of learning content with perceived e-learning quality, and

(3) Investigate the impact of overall e-learning quality on students' satisfaction in the context of Bangladesh.

\section{Literature Review}

Education through online platforms requires a collaborative effort between teachers and students, which sometimes requires more open innovative processes than the traditional teaching system. Teachers must play the role of instructor or facilitator with the source of knowledge sharing to improve student satisfaction. The acceptance of new and open innovative learning methods strongly depends on how consumers perceive the benefits of distance learning, the requirements of technical and environmental support, the effectiveness, efficiency, and equality of learning, and many other factors [16]. The central idea behind this technique is to treat students as end users; accordingly, institutions or universities should make an honest effort to offer the best education services to students [17]. Measuring the satisfaction of students, meeting minimum standards, and achieving quality excellence are the principal goals for universities $[16,18]$. 
Quality has been characterized as the buyer's general impression about the relative superiority and inferiority of an organization and the services offered by it $[19,20]$. Perceived quality is the mentality behind a customer's judgment of the performance of products and services. In the service industry, service quality is generally assessed by the outcome of the service delivery system. Service quality is the perception of customers and is linked to behavioral intentions. Perceived service quality can be termed as 'a global judgment or attitude relating to the superiority of a service' [18]. In the context of e-learning, service quality is defined as the variation between the service expectation and learners' perceived experience [17]. Parasuraman et al. [21,22] were among the first to identify service quality in the service-oriented industry, introducing the SERVQUAL model. They identified ten parts of the model: reliability, tangibles, responsiveness, credibility, courtesy, competency, security, communication, access, and understanding the customer. Subsequently, Berry et al. [23] further investigated these connections and highlighted five measurements-tangibility, responsiveness, reliability, empathy, and assurance-which lay behind SERVQUAL [20,21,24].

Over the past few years, various studies have endeavored to address key aspects of service quality influence in internet commerce directly and indirectly. In the context of the electronic industry, Gefen [25] identified five service quality measurements and reduced them to three which help online quality: (a) tangibles; (b) the combined dimension of reliability, responsiveness, and assurance; and (c) empathy. Barnes and Vidgen [26] identified a unique scale to measure organizations' commerce offerings, which is called Web-Qual. This scale gives an indicator of a website's quality using five dimensions of usability, information, design, empathy, and trust. Wolfinbarger et al. [27] developed a 14-item scale with four attributes: website design, privacy/security, reliability/fulfillment, and customer service. Based on a thorough review and evaluation of the existing literature on e-service quality, Parasuraman et al. [28] identified five broad sets of criteria: ease of use or usability, content and information availability, privacy/security, graphics style, and reliability/fulfillment. Not all dimensions of the SERVQUAL model have the same effect on all types of customers and in every context. Researchers have distinguished factors in different categories and proposed different models to justify their impact on customer judgment. Han and Baek [29] designed four-factor measurement scales-tangibles, reliability, responsiveness, and empathy - for determining e-service quality. In another study, Yang et al. [30] explored attentiveness, credibility, access, security, ease of use, and reliability as the significant dimensions for measuring e-service quality. Lin [31], Wang et al. [32], and DeLone and McLean [33] divided these factors into three major categories—service quality, information quality, and system quality.

To measure the gap between customer experience and expectation, the SERVQUAL model may perform as a significant tool. Li et al. [34] explored students' expectations and perceptions regarding the service quality of e-learning and found a significant gap between the students' expectations and perception of service quality. Among the five dimensions, assurance encompassed the highest level of perception, whereas empathy contained at least one. To measure e-learning quality, Ehlers [35] emphasized the significance of course content and interaction among 30 dimensions, which was also supported by the findings of Yang and Liu [36]. Subsequently, Udo et al. [37] proposed a modified model consisting of website content and the dimensions of the SERVQUAL instrument, and they found a positive impact of responsiveness, empathy, assurance, and website content on perceived e-learning quality. Many researchers have argued for the influence of informative and persuasive websites on perceived quality criteria. According to Iverson and Colky [38], a successful e-learning website is characterized as pleasurable and engaging, positive and helpful, dynamic, collaborative, and contextual. Considering the service factors, the content of learning and system of delivery are also crucial constructs for user satisfaction. From an e-learning perspective, 'learning content' is defined as accurate and accessible materials delivered to students in a timely and concise manner [39]. To highlight the importance of system and information quality, Uppal et al. [39] included learning content 
and course website with the SERVQUAL model and found a positive correlation between the student perception of ELQ with tangibility, responsiveness, assurance, learning content, and course website. This study is based on the theoretical foundations of e-service quality in the context of e-commerce, which has been applied by many researchers in the field of e-learning to measure the satisfaction level of e-learners [37,39-41].

According to Al-Rahmi et al. [42], students perceive high levels of relationship between e-learning content, e-learning personalization, e-learning community, and e-learning selfefficacy with e-learning satisfaction. In another study, Pham et al. [43] considered e-learning system quality, administrative and support service quality, and course materials and instructor quality as the important dimensions that contribute to measuring the overall e-learning service quality, which impacts satisfaction and loyalty. Most researchers have found an interrelationship between service quality and perceived e-learning quality. Wang and Sheih [44] found that the relationship and positive influence of service quality on customer satisfaction was supported by other findings [45,46]. Although various e-learning service quality dimensions have been identified by different e-learning service investigators, it is beneficial to confirm these results regarding which dimensions comprise the service quality of e-learning and whether they have different effects in crises. Therefore, this study focuses on end-users to explore the influence of the determinants of service quality on their perceptions of online learning service quality.

\section{Conceptual Modeling and Hypothesis Development}

E-learning is distinctive from the conventional learning process and is affected by a different set of determinants. This study adopts the SERVQUAL model, which is a popular multidimensional instrument to measure customer perception and satisfaction applied by Stodnick and Rogers [17] and Uppal et al. [39] in their study in the learning platform. To measure customer's perception of e-learning quality, five constructs of the SERVQUAL model were used in this study ('website design', which replaces tangibility, and reliability, responsiveness, assurance, and empathy) along with 'learning content' to measure e-learners' perception of their institution's efforts. Learning through the internet reveals a new orientation to the learners, and a systematic evaluation of the e-learning service delivery process may improve its effectiveness.

\subsection{Reliability}

Reliability is a fundamental element of the SERVQUAL model that affirms the ability to provide services timely, exactly, and credibly. It is important to ensure consistency in providing e-learning services and fulfill the commitment to be reliable to customers.

Wolfinbarger et al. [27] found that reliability is the strongest predictor of customer satisfaction and quality. Zeithaml et al. [47] defined reliability as the capability of correcting technical functioning and providing the promised services accurately and dependably. Many authors have argued that providing accurate information on a website is the crucial determinant of reliability $[36,48]$. With the fulfillment of promises, reliability increases trust in and dependability on the organization. This study adopted the reliability dimension as one of the important determinants of e-learners' perceived service quality. As an information-based service, reliability is considered an important aspect and has a direct impact on perceived service quality and satisfaction $[49,50]$.

Hypothesis 1 (H1). Reliability has a positive impact on students' perceived e-learning quality.

\subsection{Responsiveness}

Responsiveness defines the willingness to respond to customers and offer speedy assistance to fulfill their needs. According to Zeithaml et al. [47], responsiveness refers to a quick response and the capability to solve problems or questions immediately. Providing customers with services and information when they require it is also termed responsiveness [21,51,52]. Customers expect appropriate responses and arrangements regarding 
electronic services. Confirming transactions and delivering the promised services are termed the responsive behavior of the service provider. The level of responsiveness can be measured by the teachers/instructors' responses to student's inquiries and to what extent they give useful feedback for their problems in a reasonable time period [53]. This item is highly relevant to the focus of this study: the customer assessment of service quality in an e-learning context.

Hypothesis 2 (H2). Responsiveness has a positive influence on students' perceived e-learning quality.

\subsection{Assurance}

When customers feel confident in dealing with the online interface and its image and reputation, this is termed as assurance. Trust and credibility are the basic foundation of any business. Parasuraman et al. [21] defined assurance as the knowledge and courtesy of employees and their capabilities to achieve the confidence and trust of their customers. In the online service industry, due to inseparability characteristics, assurance plays a very significant role in the users' perception of service quality. Researchers have suggested different dimensions to measure assurance, such as security of the transaction, privacy of sensitive information, and credibility [54-56]. The efficient and proper handling of customer's queries and complaints may increase the speediness of e-learning services for new users.

Hypothesis 3 (H3). Assurance has a positive impact on students' perceived e-learning quality.

\subsection{Empathy}

Organizations should provide services on a priority basis, and customers need to feel this. Empathy implies caring, giving individual attention, and offering assistance to customers [57]. Customers always want to feel unique and special, which is the main focal point of empathy [57]. According to Kassim and Abdullah [58], empathy is defined as customized/individualized caring and the special attention paid service providers to their customers. Students who come from different backgrounds and cultures face different types of problems. Caring for and paying individual attention to every student increases the level of satisfaction. Students evaluate institutions positively when they feel that institutions are trying to provide individual services according to their personal needs [53]. Many researchers have focused on empathy determinants to establish their impact on perceived service quality measurement [37,39].

\section{Hypothesis 4 (H4). Empathy has a positive effect on students' perceived service quality.}

\subsection{Learning Content}

The e-learning platform plays a vital role in aiding learning content and communicating with students in organizational learning $[59,60]$. According to The Swedish National Agency for Higher Education [61], material/content and the virtual environment (website content) are considered important constructs among the many quality evaluation dimensions of the e-learning quality model. Student engagement with e-learning is highly related to the relevancy of learning content. The sharing of updated institutional and pedagogical material increases positive responses among learners [11]. Learning content is defined as 'accessible and accurate learning material provided to students in a concise and timely fashion' [39]. Learning content assimilation and the delivery roles of the instructors are unique and important in the electronic education system. Learning content on websites ensures that learners can review the content at any time and at their convenience. Uppal et al. [39] studied 'learning content' as an information dimension and found a positive influence on e-learners' perception. 'Learning content' quality factors are identified in the literature as structure [62], updated learning material [11], and sufficient learning material [63]. Given the above, it is justified for a study to measure the effect of learning content on the learner's perceived quality, and the formulated hypothesis is as follows: 
Hypothesis 5 (H5). Learning content has a positive impact on students' perceived e-learning quality.

\subsection{Website Design}

The 'website design' construct has replaced 'tangibility', as tangibles are partly covered by the appearance of websites [25,37]. A course website performs as a medium of e-learning, as justified by many researchers $[36,64,65]$, and it affects learners' perceived quality. Informative and accurate content on websites enriches the customer's understanding and encourages the use of website services. The use of multimedia (audio, visual, and graphics) and the website's accuracy and utility value increase its acceptance to users. Communication and the sharing of educational materials between instructors and e-learners occur through a website medium. Web design and layout, the availability of multimedia, and web content are the major web attributes affecting e-learning experience and perceived quality [66]. Web site features are closely associated with the core evaluation process and positively influence customer attitudes and behavioral intentions [67]. According to Iverson and Colky [38], a successful e-learning website is enjoyable and engaging, positive and supportive, active, collaborative, and contextual. During a pandemic, website design should be easy to navigate and supply useful information to develop the relationship between the instructor and the learners [68].

Hypothesis 6 (H6). Website design has a positive impact on students' perceived e-learning quality.

\subsection{Perceived E-Learning Quality and Satisfaction}

Satisfaction can be described as the customer's fulfillment reaction to a service obtained from passionate evaluation and emotional assessment. According to Oliver [69], customer satisfaction is defined as matching the expectation of services and products. When the perceived performance matches or exceeds customers' expectations, satisfaction arises, and if it does not, then dissatisfaction occurs [70-73]. Subsequently, positive (or negative) perceptions of customers regarding the quality of different service dimensions will lead to satisfaction (or dissatisfaction) with the online services offered through websites [74]. Students' satisfaction can be characterized as a personal assessment backed by educational knowledge, understanding, and facilities. In terms of internet learning, e-learner satisfaction is considered one of the focal segments for recognizing the attributes of elearning $[75,76]$. Numerous studies have confirmed that electronic learning service quality influences e-learners' satisfaction [44,77]. In the COVID-19 pandemic, when e-learning has become the only way of knowledge sharing worldwide [78], students' perceived learning acts as a major determinant of student satisfaction [79].

Hypothesis 7 (H7). Perceived service quality has a positive influence on e-learners' satisfaction.

To improve learning knowledge, e-learning requires modern technology and learners' experience $[13,80,81]$. Therefore, this study attempts to investigate the perception of service quality of the end-users as students. Thus, this study highlights the satisfaction level that arises from users' positive experiences. Figure 1 shows the proposed research framework of the present study and the hypotheses. 


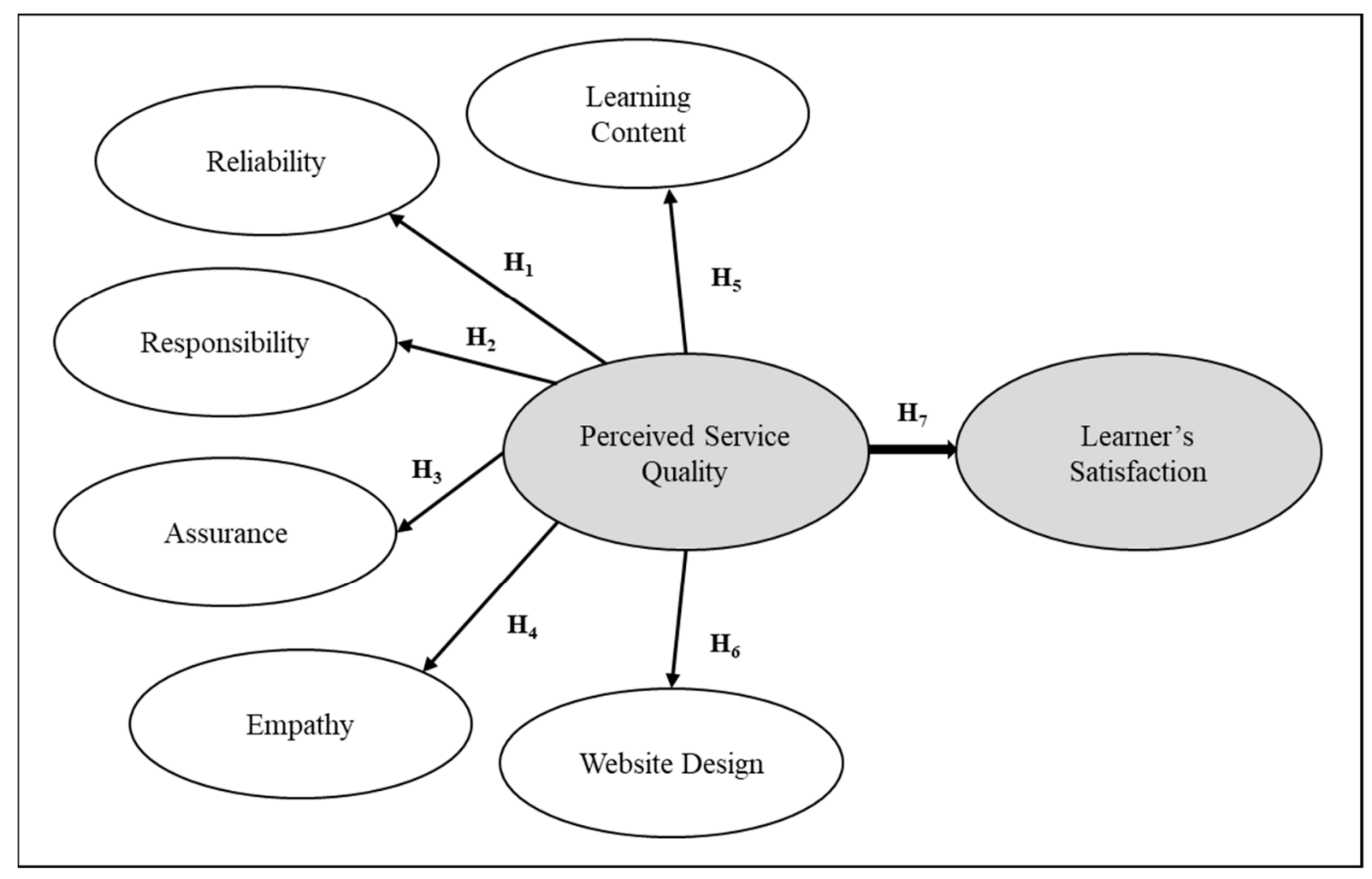

Figure 1. Proposed research model.

\section{Methodology}

After reviewing the prior literature, a conceptual model was developed to measure e-learning service quality in the Bangladeshi context. After a successful experiment, most Bangladesh universities have launched interactive courses and classes, with a combination of live sessions and pre-recorded materials according to academic routine. In these circumstances, e-learning has been performed with the assistance of Google Meet, Zoom, and video communication systems for online classes and exams, resulting in publishing and admissions, etc. Among the six items, reliability, responsibility, assurance, and empathy belong to the SERVQUAL model and were adapted from Parasuraman et al. [21], whereas 'website design' and 'learning content' were adapted from Gefen [25] and Cao et al. [66], respectively. Items related to reliability, responsiveness, assurance, and empathy are taken from Sohail and Hasan [44] and Udo et al. [37]; learning content is taken from Kumar [60], and website design is taken from Cao et al. [66]. Initially, a questionnaire was developed comprising 39 items that measured the e-learning service quality that the students experience in their current online classes and other pedagogy courses. Two-step processes were conducted to ensure the content validity of the questionnaire. In one group, five experts were selected who are involved with teaching on online platforms and possess expertise in ICT, e-commerce, and service quality measurement. In another group, 10 students were selected who have experience in online learning and have already completed different online courses. Depending on their suggestions, 10 items were deleted, and a revised questionnaire was prepared to collect the respondents' data. The questionnaire was prepared in two languages, English and Bengali.

\subsection{Data Collection Process}

The target respondents were recruited from two leading public universities in Dhaka and Chittagong, Bangladesh. The student respondents are studying as graduates and postgraduates in different disciplines. The questionnaire was sent to the respondents through their teachers and instructors, and they were requested to fill it in with their responses. The questionnaire was sent through an online format-'Google Form'. The 
online survey was continued for a 3-week duration from 15 March 2021 to 7 April 2021. Initially, the questionnaire was sent to 1000 respondents, and 927 responses were returned. Among these, 12 responses were incomplete, and 895 responses were considered for further analysis purposes. Table 1 shows the respondents' demographic profile.

Table 1. Respondents' demographic profile.

\begin{tabular}{|c|c|c|c|}
\hline Constructs & Classification & Frequency & Percentage \\
\hline \multirow{2}{*}{ Gender } & Male & 509 & 56.87 \\
\hline & Female & 386 & 43.13 \\
\hline \multirow{4}{*}{ Age } & $19-20$ & 12 & 1.34 \\
\hline & $21-22$ & 639 & 71.40 \\
\hline & $23-24$ & 179 & 20.00 \\
\hline & $25-26$ & 65 & 7.37 \\
\hline \multirow{2}{*}{ Level of study } & Undergraduate & 676 & 75.53 \\
\hline & Postgraduate & 219 & 24.47 \\
\hline \multirow{6}{*}{$\begin{array}{l}\text { Discipline/Program } \\
\text { Background }\end{array}$} & BBA (Honors) & 238 & 26.59 \\
\hline & BSc. Sciences & 195 & 21.79 \\
\hline & BSS Arts & 177 & 19.78 \\
\hline & MBA & 147 & 16.42 \\
\hline & BSS Arts & 86 & 9.60 \\
\hline & MSc. Sciences & 52 & 5.81 \\
\hline \multirow{3}{*}{ Course types } & Live class & 240 & 26.82 \\
\hline & Recorded class & 199 & 22.23 \\
\hline & Both & 456 & 50.94 \\
\hline \multirow{5}{*}{ Frequency of use online class (Daily) } & Below $1 \mathrm{~h}$ & 154 & 17.21 \\
\hline & $1-3 \mathrm{~h}$ & 396 & 44.13 \\
\hline & $3-5 h$ & 312 & 34.86 \\
\hline & $5-7 \mathrm{~h}$ & 33 & 3.68 \\
\hline & more than $7 \mathrm{~h}$ & 0 & 0 \\
\hline
\end{tabular}

\subsection{Measurement Model}

The objective of using a measurement model is to clarify how well the predictor indicators act as a measurement tool for the hidden variables. Before testing the multiple aspects of the hypothesized model, it is vital to measure the reliability and validity of the instrument. Table 2 shows the factor loadings, composite reliability (CR), and average variance extracted (AVE) for perceived service quality and learner's satisfaction in the institution's effort in instruments. Internal consistency refers to the extent to which all markers are diverse from one another and how much the (sub) scale assesses an identical idea [82]. Composite reliability estimates for all constructs are higher than 0.80 (Table 2), which confirms the threshold level $\geq 0.70$ as recommended by Bagozzi and Yi [83].

Convergent validity is satisfactory when the AVE is greater than 0.50 [84], which is confirmed in this study, as shown in Table 2. 
Table 2. Standardized factor loadings, composite reliability, and average variance extracted.

\begin{tabular}{|c|c|c|c|c|}
\hline Constructs & Items & $\begin{array}{l}\text { Standardized } \\
\text { Factor Loadings }\end{array}$ & C.R & AVE \\
\hline \multirow{3}{*}{ Reliability $[39,68]$} & Re1: Provide accurate information & 0.859 & \multirow{3}{*}{0.853} & \multirow{3}{*}{0.659} \\
\hline & Re2: Correct performances & 0.814 & & \\
\hline & Re3: Fulfill promises & 0.760 & & \\
\hline \multirow{3}{*}{ Responsiveness $[39,68]$} & Rs1: Prompt service & 0.853 & \multirow{3}{*}{0.825} & \multirow{3}{*}{0.613} \\
\hline & Rs2: Willingness to solve problem fast & 0.774 & & \\
\hline & Rs3: Responses according to user's need & 0.717 & & \\
\hline \multirow{3}{*}{ Assurance $[39,68]$} & As1: Instructors are knowledgeable in their field & 0.860 & \multirow{3}{*}{0.841} & \multirow{3}{*}{0.640} \\
\hline & As2: Provide secure transaction facilities & 0.788 & & \\
\hline & As3: I feel confident in e-learning services & 0.748 & & \\
\hline \multirow{3}{*}{ Empathy $[39,68]$} & $\begin{array}{l}\text { Em1: Institutions are genuinely concerned } \\
\text { about students }\end{array}$ & 0.830 & \multirow{3}{*}{0.836} & \multirow{3}{*}{0.631} \\
\hline & $\begin{array}{l}\text { Em2: Institutions are caring for the individual needs } \\
\text { of students }\end{array}$ & 0.775 & & \\
\hline & Em3: Instructors motivate and encourage students & 0.777 & & \\
\hline \multirow{3}{*}{ Learning content $[63,85]$} & LC2: Learning content is well-structured & 0.941 & \multirow{3}{*}{0.903} & \multirow{3}{*}{0.758} \\
\hline & LC2: Learning materials are up-to-date & 0.873 & & \\
\hline & LC3: Sufficient learning material available & 0.791 & & \\
\hline \multirow{4}{*}{ Website design $[39,63]$} & WD1: Provides relevant information & 0.892 & \multirow{4}{*}{0.889} & \multirow{4}{*}{0.546} \\
\hline & WD2: Easy to use & 0.882 & & \\
\hline & WD3: Speed of completing transaction & 0.782 & & \\
\hline & WD4: Attractive and well designed & 0.672 & & \\
\hline \multirow{3}{*}{ Perceived quality [85] } & PQ1: The e-learning services is very contemporary & 0.875 & \multirow{3}{*}{0.821} & \multirow{3}{*}{0.610} \\
\hline & PQ2: The quality of the instructors is good & 0.836 & & \\
\hline & $\begin{array}{l}\text { PQ3: The overall quality of e-learning services } \\
\text { is excellent }\end{array}$ & 0.605 & & \\
\hline \multirow{3}{*}{ Satisfaction [79] } & Sa1: I am satisfied with the e-learning services & 0.980 & \multirow{3}{*}{0.864} & \multirow{3}{*}{0.684} \\
\hline & Sa2: I will recommend e-learning services to others & 0.771 & & \\
\hline & Sa3: My enrollment decision is right & 0.706 & & \\
\hline
\end{tabular}

According to Hair et al. [84], discriminant validity is 'the degree to which two conceptually similar constructs are distinct'. When the correlation coefficient between any pair of constructs is smaller than 0.85 and the square root of the AVE is greater than the subsequent correlation coefficient, discriminant validity is considered met $[85,86]$. Table 3 shows that most of the correlation coefficients between two constructs are smaller than 0.85 , and most of the square roots of the AVE estimates are greater than the corresponding correlations coefficient. 
Table 3. Discriminant validity.

\begin{tabular}{ccccccccc}
\hline & Re & Rs & As & Em & LC & WD & PQ & Sa \\
\hline Re & $\mathbf{0 . 7 8 0}$ & & & & & & & \\
\hline Rs & 0.726 & $\mathbf{0 . 7 8 3}$ & & & & & & \\
\hline As & 0.696 & 0.698 & $\mathbf{0 . 8 4 5}$ & & & & & \\
\hline Em & 0.690 & 0.626 & 0.786 & $\mathbf{0 . 8 2 7}$ & & & & \\
\hline LC & 0.688 & 0.612 & 0.682 & 0.783 & $\mathbf{0 . 8 2 4}$ & & & \\
\hline WD & 0.666 & 0.568 & 0.648 & 0.634 & 0.698 & $\mathbf{0 . 8 3 5}$ & & \\
\hline PQ & 0.655 & 0.547 & 0.599 & 0.627 & 0.664 & 0.715 & $\mathbf{0 . 7 8 2}$ & \\
\hline Sa & 0.643 & 0.491 & 0.505 & 0.596 & 0.642 & 0.692 & 0.698 & $\mathbf{0 . 9 0 4}$ \\
\hline
\end{tabular}

Note: The bold values in the diagonal scales are the square root of AVE. Re: Reliability; Rs: Responsibility; As: Assurance; Em: Empathy, WD: Website Design; LC: Learning Content; PQ: Perceived Quality; Sa: Satisfaction.

\subsection{Structural Equation Modeling and Hypothesis Testing}

To estimate the underlying relationship amongst variables, structural equation modeling (SEM) was applied in this study to analyze the data. The results of the model fit statistics are presented in Table 4 . The acceptance goodness-of-fit indices were $\chi^{2} / \mathrm{df}=2.388$, $\mathrm{GFI}=0.956, \mathrm{NFI}=0.908, \mathrm{CFI}=0.927, \mathrm{RMSEA}=0.043$. According to Hair et al. [84], Hwang and Min [87], Browne and Cudek [88], and Hooper et al. [89], all the values met the threshold level.

Table 4. Summary of goodness-of-fit indices.

\begin{tabular}{cccc}
\hline Index & Value & Threshold Level & References \\
\hline CMIN & 392.17 & & \\
\hline DF & 197 & 1 to 3 & \\
\hline CMIN/DF & 2.388 & $<0.08$ & \\
\hline RMR & 0.067 & $>0.9$ & \\
\hline GFI & 0.956 & $>0.9$ & \\
\hline AGFI & 0.980 & $>0.9$ & \\
\hline NFI & 0.908 & $>0.9$ & \\
\hline CFI & 0.927 & $<0.06$ & \\
\hline RMSEA & 0.043 & $>0.05$ \\
\hline P close & 0.067 &
\end{tabular}

SEM was conducted to measure the parameters of perceived service quality and student satisfaction. Figure 2 shows the impact of the structural model of e-learning SERVQUAL dimensions on perceived service quality and e-learning satisfaction $(p<0.001)$ In the first order, this model begins with the constructs of the SERVQUAL scale, consisting of a six-dimension structure of reliability, responsibility, assurance, empathy, website design, and learning content, to measure the e-learning service quality. The dimensions reliability, responsibility, assurance, empathy, and learning content were measured by three indicators; website design was measured by four indicators. Meanwhile, learner's satisfaction and perceived service quality were measured by three indicators. 


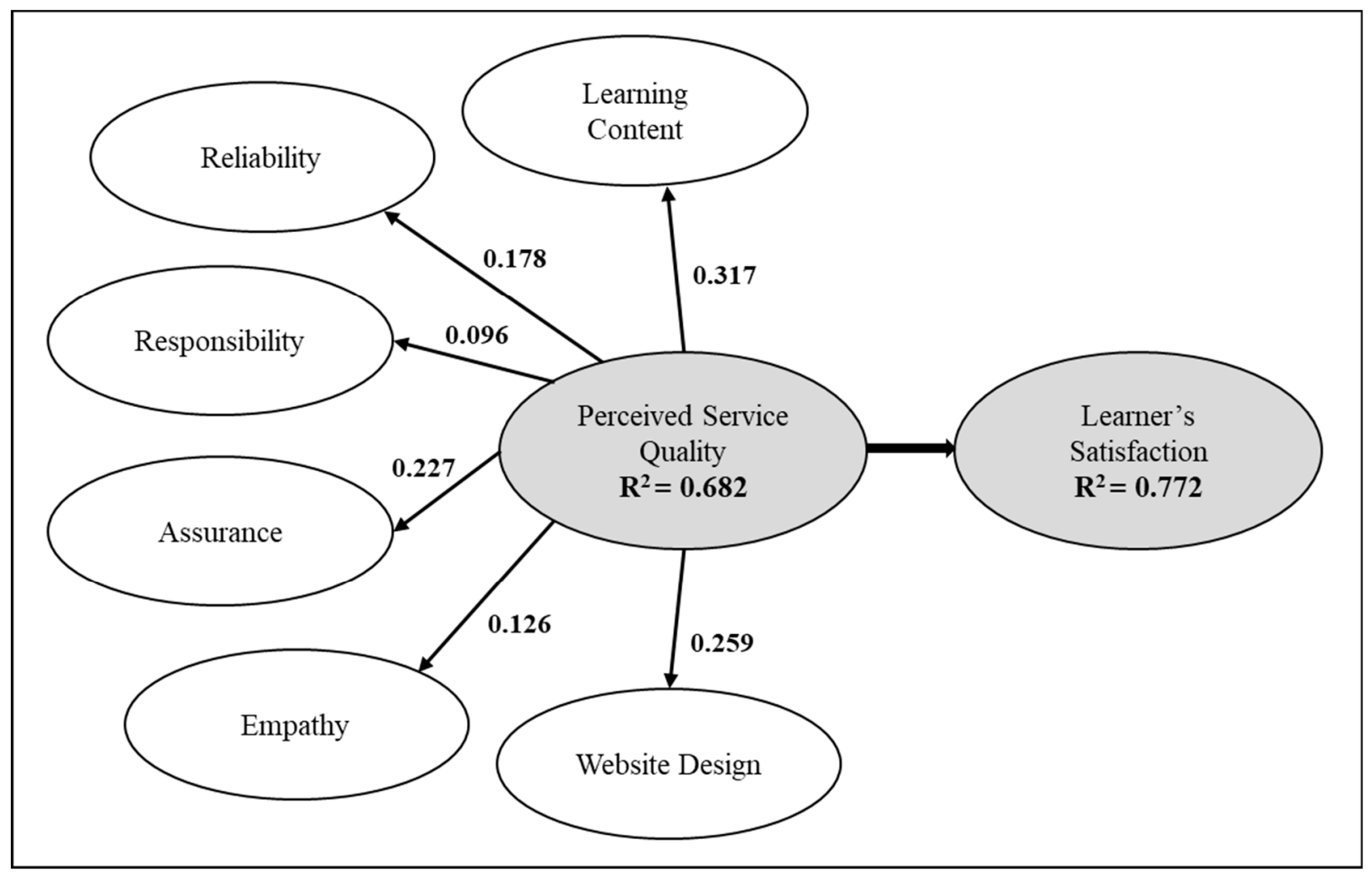

Figure 2. Structured model with path coefficients.

Table 5 shows the standardized parameter estimates, path coefficients, and the significant values for the hypothesis relationships. The significant path coefficient shows that learning content and website design have the most important influence on perceived service quality, followed by assurance, reliability, empathy, and responsiveness, respectively. The standardized path coefficient was 0.317 for learning content, 0.259 for website design, 0.227 for assurance, 0.178 for reliability, 0.126 for empathy, and 0.096 for responsiveness. The six hypotheses were tested as independent variables. All the six independent variables are positively connected with perceived service quality, but among them, five variables (reliability, assurance, empathy, learning content, and website design) significantly influenced the overall perception of students. The result also indicates that the perceived service quality of e-learning has a positive impact on the e-learner's satisfaction ( $\beta=0.587$, $p=0.001$ ); thus, H7 is supported.

Table 5. Standardized regression weight for path coefficients.

\begin{tabular}{|c|c|c|c|c|c|c|}
\hline Hypothesis & & Estimate & S.E & C.R & $p$-Value & Decision \\
\hline $\mathrm{H} 1$ & Perceived Quality $\leftarrow$ Reliability & 0.178 & 0.057 & 2.756 & 0.005 & Supported \\
\hline $\mathrm{H} 2$ & Perceived Quality $\leftarrow$ Responsibility & 0.096 & 0.042 & 0.978 & 0.75 & Not supported \\
\hline H3 & Perceived Quality $\leftarrow$ Assurance & 0.227 & 0.062 & 3.156 & $* * *$ & Supported \\
\hline $\mathrm{H} 4$ & Perceived Quality $\leftarrow$ Empathy & 0.126 & 0.051 & 2.145 & 0.010 & Supported \\
\hline H5 & Perceived Quality $\leftarrow$ Learning Content & 0.317 & 0.069 & 5.069 & $* * *$ & Supported \\
\hline $\mathrm{H} 6$ & Perceived Quality $\leftarrow$ Website Design & 0.259 & 0.063 & 3.876 & $* * *$ & Supported \\
\hline $\mathrm{H} 7$ & User's Satisfaction $\leftarrow$ PerceivedQuality & 0.587 & 0.065 & 4.076 & $* * *$ & Supported \\
\hline
\end{tabular}


Regarding the $R^{2}$ values required to study the explanatory power of the model, the collective effect of the six dimensions (reliability, responsibility, assurance, empathy, learning content, and website design) achieved $68 \%$ of the variance on perceived service quality $\left(R^{2}=0.682\right)$. In addition, the effect of perceived service quality on e-learners satisfaction achieved a $77 \%$ variance $\left(R^{2}=0.772\right)$. The analysis indicates that measures of service quality have adequate explanatory power and thus can calculate e-learners' satisfaction effectively.

\section{Discussion}

Teaching and learning through electronic technology ensures limited social gathering and is the principal medium of learning in pandemic situation. The new technological innovation dynamics offer huge potential for the students to continue their study and communications with the teachers and instructors. However, the rate of adoption and adaptability of this new virtual platform depends significantly on learners' positive perception and satisfaction. Therefore, this current study attempts to explain the overall perception and satisfaction of students with e-learning using the extended SERVQUAL model. In this study, 'learning content' was added and tangibility was replaced with 'website design', as suggested by Gefen [25], Parasuraman et al. [28], and Uppal et al. [39], along with the other instruments of the SERVQUAL model, to identify their impact on e-learners' perceptions. The results of this study indicate that all the determinants of the proposed model have a positive influence on perceived quality and satisfaction, which is consistent with the results of other studies $[36,37,39]$. The results also confirm that except for responsiveness, other constructs (reliability, assurance, empathy, website design, and learning content) are positively related with users' perceived service quality [39], influencing their satisfaction [37].

It is apparent that as new technology-based learning, students search for accurate, dependable, and reliable online services. In this regard, reliability has a noteworthy impact on perceived quality, as supported by the findings of many studies $[17,27,91]$. Responsiveness has been found to be a significant determinant in many studies [37,39,92], whereas the findings of this study indicate the insignificant impact of responsiveness on perceived service quality, which supports Stodnick and Rogers [17]. The possible explanation for the insignificant impact of 'responsiveness' may be because students are also aware of the lack of capabilities of the institutions and instructors to provide prompt and immediate responses due to lockdown. Students are looking for customer-centric services from instructors or teachers and seek personalized attention for each individual. Therefore, the results show that empathy and assurance have a strong influence on the dependent variables, supporting other studies $[17,37]$.

In electronic-based transactions, the website functions as a physical setting that ensures the availability of learning courses and material accurately and concisely. An effective and informative website helps to increase personalization and product-selecting benefits. In this study, 'website design' was included as a predictor and was found to have a strong significant influence on perceived quality measurement. Some previous studies have also identified the same result $[28,37,39,63]$ and mentioned its importance in the e-learning context.

To enhance the perceived usefulness of e-learning systems, the learning content and course material perform a very important role [93]. During the pandemic, students desire up-to-date and relevant course material on online platforms. This study also affirms the importance of learning content and found that it had the highest significant impact on perception and satisfaction variables. One possible explanation is that because of the forced shutdown of educational institutions due to the COVID 19 pandemic, face-to-face classroom learning was paused. Students become worried about their continuation of study and access to course materials. To maintain student's interest in online learning, there is no alternative to the availability of well-structured and sufficient course materials on online platforms. 
The findings also indicate a direct and significant positive relationship between perceived service quality and satisfaction. These results support the previous studies applicable for both traditional and online learning methods $[17,37,41,42,94]$. Therefore, the significant impact of SERVQUAL dimensions on perceived quality and satisfaction suggest their importance in achieving competitiveness, greater value, growth of service opportunities, and satisfaction.

\section{Managerial Implications}

On the online platform, e-users found that e-learning can be managed simply, and learners can contact teachers and teaching material easily [95]. The rapid global advancement in the electronic platform begins new pursuits and extents of e-learning need to ensure its quality and standard. The online learning system is relatively new and an innovative teaching approach in Bangladesh [96]. Insufficient training, poor user experience, and little preparation have resulted in unplanned online learning in developing countries. Therefore, the findings of this study provide an understanding of the determinants that affect customers' perceived quality and satisfaction toward e-learning services. Management and authorities should consequently pay attention to the findings of this study and how these determinants (reliability, responsibility, assurance, empathy, website design, and learning content) were evaluated by the e-learners. This research significantly contributes to the literature by highlighting the accumulated impact of service quality attributes on perceived quality and satisfaction in a developing country context such as Bangladesh in a pandemic situation. The proposed attributes are yet to be previously studied in a pandemic situation and may contribute to the knowledge of policymakers of universities in reviewing and applying the effective usage of e-learning systems. Similar to other developing countries, Bangladesh also suffers from some major challenges such as the lack of readiness from both students' and universities' perspectives. Therefore, the results of this study may guide the government and authorities in policy development to maintain quality standards that achieve users' satisfaction in general.

\section{Conclusions}

To increase the popularity and utilization of online education platforms, customer services play a significant role in diagnosing their problems and preventing wasted learning time. In this study, a modified SERVQUAL model was applied to measure e-learner satisfaction. The findings indicate that the determinants of SERVQUAL instruments have a positive impact on the perception of students measuring service quality, which has a direct effect on satisfaction. If service quality is good, then learner satisfaction can be more effectively achieved, which in turn makes the learners loyal to the e-learning process.

A successful e-learning system covers technical issues, management issues, cultural issues, and financial support issues. The introduction of an effective electronic learning platform requires an accumulated effort from all stakeholders. To maintain an uninterrupted learning process, the government should work with other authorities to remove technological barriers, investing in digital infrastructure development and offering cost-effective learning to students. A better-integrated system may ensure the highest participation and satisfaction of e-learners.

This study reveals that learning contents and materials have a great influence on the perception of students considering service quality. Proper attention of the instructors, teachers, and administrators toward content development and continuous improvement may increase engagement and satisfaction among e-learners. To develop the ICT and pedagogical skills and knowledge of the teachers and instructors, proper training programs should be introduced. A strong promotional effort may support teachers, students, parents, and facilitators in the successful use of e-learning materials. Another important facet is that website service quality influences user satisfaction. To improve their efficiency at e-learning, universities should ensure their website offers informative and corresponding website attributes. The dimensions of the SERVQUAL model (reliability, assurance, empathy) 
have a significant impact on user satisfaction, with the exception of responsiveness. The competency, efficiency, dependability, performance, and customized service-providing capabilities of employees and instructors highly influence users' perception and satisfaction. Therefore, university authorities should focus on these perceptual attributes.

This study only highlighted the perception of the students but may not be representative in the general concept. Future studies covering the teacher's and instructor's perspectives can provide a large picture of the e-learning system. Here, researchers mainly focused on the quality of services students' receive in their learning process through online platforms. Furthermore, studies can examine the application of tools for assessing and improving the quality of e-learning courses, specially focusing on the contents and materials $[97,98]$ in the context of emerging countries. The geographic location of the respondents may be considered as a limitation. Bangladesh is characterized as a developing country facing some major crises of low literacy rate, underdeveloped technology infrastructure, poor internet facilities, and low-income level, which affects the readiness of any new technological innovation. Finally, determining an acceptable quality model is a very critical step. More studies in this area may uncover new dimensions which is a challenge for this study.

Author Contributions: Conceptualization, R.S.S.; methodology, R.S.S.; software, R.S.S.; validation, R.S.S. and G.K.; formal analysis, R.S.S.; investigation, R.S.S.; resources, R.S.S. and G.K.; data curation, R.S.S.; writing—original draft preparation, R.S.S.; writing—review and editing, R.S.S. and G.K.; visualization, R.S.S. and G.K.; project administration, R.S.S. All authors have read and agreed to the published version of the manuscript.

Funding: This research received no external funding.

Institutional Review Board Statement: Not applicable.

Informed Consent Statement: Not applicable.

Data Availability Statement: All data generated or analyzed during this study are included in this published article.

Conflicts of Interest: The authors declare no conflict of interest.

\section{References}

1. Tsai, C.; Shen, P.; Chiang, Y. The application of mobile technology in e-learning and online education environments: A review of publications in SSCI-indexed journals from 2003 to 2012. Int. J. Enterp. Inf. Syst. 2013, 9, 85-98. [CrossRef]

2. $\mathrm{Wu}, \mathrm{B}$. Identifying the influential factors of knowledge sharing in e-learning 2.0 systems. Int. J. Enterp. Inf. Syst. 2016, 12, 85-102. [CrossRef]

3. Agarwal, S.; Kaushik, J.S. Student's perception of online learning during COVID pandemic. Indian J. Pediatrics 2020, 87, 554. [CrossRef]

4. $\quad$ Agung AS, N.; Surtikanti, M.W.; Surtikanti, M.W. Students' Perception of Online Learning during COVID-19 Pandemic: A Case Study on the English Students of STKIP PamaneTalino. SOSHUM J. Sos. Dan Hum. 2020, 10, 225-235. [CrossRef]

5. Xue, E.; Li, J.; Xu, L. Online education action for defeating COVID-19 in China: An analysis of the system, mechanism and mode. Educ. Philos. Theory 2020, 1-13. [CrossRef]

6. Mishra, L.; Gupta, T.; Shree, A. Online teaching-learning in higher education during lockdown period of COVID-19 pandemic. Int. J. Educ. Res. Open 2020, 1, 100012. [CrossRef]

7. Rahman, M.S.; Peeri, N.C.; Shrestha, N.; Zaki, R.; Haque, U.; Ab Hamid, S.H. Defending against the Novel Coronavirus (COVID19) Outbreak: How Can the Internet of Things (IoT) Help to Save the World? Health Policy Technol. 2020, 9, 136-138. [CrossRef] [PubMed]

8. Chin, A.; Simon, G.L.; Anthamatten, P.; Kelsey, K.C.; Crawford, B.R.; Weaver, A.J. Pandemics and the future of human-landscape interactions. Anthropocene 2020, 31, 100256. [CrossRef]

9. Khan, M.A.; Nabi, M.K.; Khojah, M.; Tahir, M. Students' Perception towards E-Learning during COVID-19 Pandemic in India: An Empirical Study. Sustainability 2021, 13, 57. [CrossRef]

10. Parvej, I.; Tabassum, M.; Mannan, S.E.; Ahmed, F. Online Education during COVID-19 in Bangladesh: University Teachers' Perspective. Aquademia 2021, 5, ep21005. [CrossRef]

11. Khan, M.M.; Rahman, S.M.T.; Islam, S.T.A. Online Education System in Bangladesh during COVID-19 Pandemic. Creat. Educ. 2021, 12, 441-452. [CrossRef] 
12. Fazlollahtabar, H.; Muhammadzadeh, A. A knowledge-based user interface to optimize curriculum utility in an e-learning system. Int. J. Enterp. Inf. Syst. 2012, 8, 34-53. [CrossRef]

13. Mystakidis, S.; Berki, E.; Valtanen, J.-P. The Patras Blended Strategy Model for Deep and Meaningful Learning in Quality Life-Long Distance Education. Electron. J. E-Learn. 2019, 17, 66-78. [CrossRef]

14. Ito, M.; Martin, C.; Pfister, R.C.; Rafalow, M.H.; Salen, K.; Wortman, A. Affinity Online: How Connection and Shared Interest Fuel Learning; NYU Press: New York, NY, USA, 2018; Volume 2, ISBN 1479888907.

15. Gress, C.L.; Fior, M.; Hadwin, A.F.; Winne, P.H. Measurement and assessment in computer supported collaborative learning. Comput. Hum. Behav. 2010, 26, 806-814. [CrossRef]

16. Barrett, A.M.; Chawla-Duggan, R.; Lowe, J.; Nikel, J.; Ukpo, E. The Concept of Quality in Education: A Review of the 'International' Literature on the Concept of Quality in Education; EdQual: Bristol, UK, 2006; Volume 3, pp. 1-9.

17. Stodnick, M.; Rogers, P. Using SERVQUAL to measure the quality of the classroom experience. Decis. Sci. J. Innov. Educ. 2008, 6, 115-133. [CrossRef]

18. Lee, W.J. Online support service quality, online learning acceptance, and student satisfaction. Internet High. Educ. 2010, 13, 227-283. [CrossRef]

19. Zeithaml, V.A.; Parasuraman, A.; Berry, L.L. Delivering Quality Service; Free Press: New York, NY, USA, 2010.

20. Taylor, S.A.; Baker, T.L. An Assessment of the Relationship between Service Quality and Customer Satisfaction in Formation of Consumers' Purchase Intentions. J. Retail. 1994, 70, 163-178. [CrossRef]

21. Parasuraman, A.; Zeithaml, V.A.; Berry, L.L. SERVQUAL: A Multiple-Item Scale for Measuring Customer Expectations of Service. J. Retail. 1988, 64, 12-40.

22. Parasuraman, A.; Zeithaml, V.A.; Berry, L.L. A conceptual model of service quality and its implications for future research. J. Mark. 1985, 49, 41-50. [CrossRef]

23. Berry, L.L.; Zeithaml, V.A.; Parasuraman, A. Quality counts in services too. Bus. Horiz. 1985, 28, 44-52. [CrossRef]

24. Choudhury, K. Evaluating customer-perceived service quality in business management education in India: A study in topsis modeling. Asia Pac. J. Mark. Logist. 2015, 27, 208-225. [CrossRef]

25. Gefen, D. Customer Loyalty in E-Commerce. J. Assoc. Inf. Syst. 2002, 3, 27-51. [CrossRef]

26. Barnes, S.J.; Vidgen, R.T. An Integrative Approach to the Assessment of E-Commerce Quality. J. Electron. Commer. Res. 2002, 3 , 114-127.

27. Wolfinbarger, M.; Gilly, M.C. eTailQ: Dimensionalizing, Measuring, and Predicting etail Quality. J. Retail. 2003, 79, 183-198. [CrossRef]

28. Parasuraman, A.; Zeithaml, V.A.; Malhotra, A. E-S-Qual: A multiple-item scale for assessing electronic service quality. J. Serv. Res. 2005, 7, 213-233. [CrossRef]

29. Han, S.; Baek, S. Antecedents and consequences of service quality in online banking: An application of the SERVQUAL instrument. Adv. Consum. Res. 2004, 31, 208-214.

30. Yang, Z.; Jun, M.; Peterson, R.T. Measuring customer perceived online service quality: Scale development and managerial implications. Int. J. Oper. Prod. Manag. 2004, 24, 1149-1174. [CrossRef]

31. Lin, H.F. The impact of website quality dimensions on customer satisfaction in the B2C e-commerce context. Total Qual. Manag. 2007, 18, 363-378. [CrossRef]

32. Wang, Y.S.; Wang, H.Y.; Shee, D.Y. Measuring e-learning systems success in an organizational context: Scale development and validation. Comput. Hum. Behav. 2007, 23, 1792-1808. [CrossRef]

33. DeLone, W.H.; McLean, E.R. The DeLone and McLean model of information systems success: A ten-year update. J. Manag. Inf. Syst. 2003, 19, 9-30.

34. Li, X.; Hess, T.J.; Valacich, J.S. Why do we trust new technology? A study of initial trust formation with organizational information systems. J. Strateg. Inf. Syst. 2008, 17, 39-71. [CrossRef]

35. Ehlers, U.D. Quality in e-learning from a learner's perspective. Eur. J. Open Distance E-Learn. 2004, 9, 45141. [CrossRef]

36. Yang, Z.; Liu, Q. Research and development of web-based virtual online classroom. Comput. Educ. 2007, 48, 171-184. [CrossRef]

37. Udo, G.J.; Bagchi, K.K.; Kirs, P.J. Using SERVQUAL to assess the quality of e-learning experience. Comput. Hum. Behav. 2011, 27, 1272-1283. [CrossRef]

38. Iverson, K.; Colky, D. Scenario-based E-learning design. Perform. Improv. 2004, 43, 16-22. [CrossRef]

39. Uppal, M.A.; Ali, S.; Gulliver, S.R. Factors determining e-learning service quality. Br. J. Educ. Technol. 2017, 49, 412-426. [CrossRef]

40. Martinez-Arguelles, M.; Batalla-Busquets, J. Perceived service quality and student loyalty in an online university. Int. Rev. Res. Open Distrib. Learn. 2016, 17, 264-279. [CrossRef]

41. Sohail, M.S.; Hasan, M. Students' perceptions of service quality in Saudi universities: The SERVPERF model. Learn. Teach. High. Educ. Gulf Perspect. 2021, 17, 54-66. [CrossRef]

42. Al-Rahmi, W.M.; Othman, M.S.; MI Yusuf, L.M. Exploring the Factors that Affect Student Satisfaction through Using E-Learning in Malaysian Higher Education Institutions. Mediterr. J. Soc. Sci. 2021, 6, 299-310. [CrossRef]

43. Pham, L.; Limbu, B.Y.; Bui, K.T.; Nguyen, T.H.; Pham, T.H. Does e-learning service quality influence e-learning student satisfaction and loyalty? Evidence from Vietnam. Int. J. Educ. Technol. High. Educ. 2019, 16, 7. [CrossRef]

44. Wang, M.I.; Sheih, C.J. The Relationship between Service Quality and Customer Satisfaction: The Example of CJCU. J. Inf. Optim. Sci. 2006, 27, 193-209. [CrossRef] 
45. Ham, L.; Hayduk, S. Gaining Competitive Advantages in Higher Education: Analyzing the Gap between Expectations and Perceptions of Service Quality. Int. J. Value-Based Manag. 2003, 16, 223-242. [CrossRef]

46. Petruzzellis, L.; D’Uggento, A.; Romanazzi, S. Student satisfaction and quality for services in Italian universities. Manag. Serv. Qual. 2006, 16, 349-364. [CrossRef]

47. Zeithaml, V.A.; Bitner, J. Mary Service Marketing, 2nd ed.; Tata McGraw-Hill Publishing Company Limited: New Delhi, India, 2000.

48. Semeijn, J.; Van Riel, A.C.R.; Van Birgelen, M.J.H.; Streukens, S. E-service and offline fulfillment: How e-loyalty is created. Manag. Serv. Qual. 2005, 15, 182-194. [CrossRef]

49. Zhu, F.X.; Wymer, W.; Chen, I. IT-Based Services and Service Quality in Consumer Banking. Int. J. Serv. Ind. Manag. 2002, 13, 69-90. [CrossRef]

50. Lee, G.; Lin, H. Customer perceptions of e-service quality in online shopping. Int. J. Retail Distrib. Manag. 2005, 33, 161-176. [CrossRef]

51. Yang, Z. Consumer Perceptions of Service Quality in Internet-Based Electronic Commerce. In Proceedings of the 30th EMAC Conference, Bergen, Norway, 8-11 May 2001.

52. Wang, M. Assessment of E-service Quality via E-satisfaction in E-commerce Globalization. 2003. Available online: https: //www.is.cityu.edu.hk/resrch/ejisdc/vol11/v11c10.pdf (accessed on 20 April 2019).

53. Vaz, A.; Mansori, S. Malaysian Private Education Quality: Application of SERVQUAL Model. Int. Educ. Stud. 2013, 6, 164-170. [CrossRef]

54. Cai, S.; Jun, M. Internet users' perceptions of online service quality: A comparison of online buyers and information searchers. Manag. Serv. Qual. 2003, 13, 504-519. [CrossRef]

55. Jun, M.; Yang, Z.; Kim, D. Customers' perceptions of online retailing service quality and their satisfaction. Int. J. Qual. Reliab. Manag. 2004, 21, 817-840. [CrossRef]

56. Long, M.; McMellon, C. Exploring the determinants of retail service quality on the Internet. J. Serv. Mark. 2004, 18, 78-90. [CrossRef]

57. Zeithaml, V.A.; Berry, L.L.; Parasuraman, A. The behavioral consequences of service quality. J. Mark. 1996, 60, 31-46. [CrossRef]

58. Kassim, N.; Abdullah, N.A. The effect of perceived service quality dimensions on customer satisfaction, trust, and loyalty in e-commerce settings: A cross cultural analysis. Asia Pac. J. Mark. Logist. 2010, 22, 351-371. [CrossRef]

59. Real, J.C.; Leal, A.; Roldán, J.L. Determinants of Organisational Learning in the generation of technological distinctive competencies. Int. J. Technol. Manag. 2006, 35, 284-307. [CrossRef]

60. Reisetter, M.; LaPointe, L.; Korcuska, J. The impact of altered realties: Implications of online delivery for learners' interactions, expectations, and learning skills. Int. J. E-Learn. 2007, 6, 55-80.

61. Swedish National Agency for Higher Education. E-learning Quality Aspects and Criteria for Evaluation of e-Learning in Higher Education. Available online: https:/ / www.diva-portal.org/smash/get/diva2:283764/FULLTEXT01.pdf (accessed on 14 October 2020).

62. Teo, C.B.; Gay, R.K.L. A knowledge-driven model to personalize e-learning. J. Educ. Resour. Comput. 2006, 6, 3. [CrossRef]

63. Kumar, P.; Saxena, C.; Baber, H. Learner-content interaction in e-learning the moderating role of perceived harm of COVID-19 in assessing the satisfaction of learners. Smart Learn. Environ. 2021, 8, 5. [CrossRef]

64. Liaw, S.S. Investigating students' perceived satisfaction, behavioral intention, and effectiveness of e-learning: A case study of the blackboard system. Comput. Educ. 2008, 51, 864-873. [CrossRef]

65. Liu, S.H.; Liao, H.-L.; Pratt, J.A. Impact of media richness and flow on e-learning technology acceptance. Comput. Educ. 2009, 52, 599-607. [CrossRef]

66. Cao, M.; Zhang, Q.; Seydel, J. B2C e-commerce web site quality: An empirical examination. Ind. Manag. Data Syst. 2005, 105, 645-661. [CrossRef]

67. Koernig, S.K. E-scapes: The electronic physical environment and service tangibility. Psychol. Mark. 2003, 20, 157-167. [CrossRef]

68. Saxena, C.; Baber, H.; Kumar, P. Examining the moderating effect of perceived benefits of maintaining social distance on e-learning quality during COVID-19 pandemic. J. Educ. Technol. Syst. 2020, 49, 532-554. [CrossRef]

69. Oliver, R.L. Satisfaction: A Behavioral Perspective on the Consumer; ME Sharpe Inc.: Armonk, NY, USA, 2009.

70. Rust, R.T.; Zahorik, A.J. Customer Satisfaction, Customer Retention, and Market Share. J. Retail. 1993, 69, 193-215. [CrossRef]

71. Oliver, R.L. Satisfaction: A Behavioral Perspective on the Consumer; McGraw-Hill: New York, NY, USA, 2010.

72. Sharifi, S.S.; Esfidani, M.R. The impacts of relationship marketing on cognitive dissonance, satisfaction, and loyalty: The mediating role of trust and cognitive dissonance. Int. J. Retail Distrib. Manag. 2014, 42, 553-575. [CrossRef]

73. Fullerton, G.; Taylor, S. Dissatisfaction and violation: Two distinct consequences of the wait experience. J. Serv. Theory Pract. 2015, 25, 31-50. [CrossRef]

74. Carlson, J.; O'Cass, A. Developing a framework for understanding e-service quality, its antecedents, consequences, and mediators. Manag. Serv. Qual. 2015, 21, 264-286. [CrossRef]

75. Bekele, T. Motivation and Satisfaction in Internet-Supported Learning Environments: A Review 2011. Educ. Technol. Soc. 2010, 13, 116-127.

76. Soffer, T.; Nackmias, R. Effectiveness of learning in online academic courses compared with face-to-face courses in higher education. J. Comput. Assist. Learn. 2018, 34, 534-543. [CrossRef]

77. Mystakidis, S. Deep and Meaningful Learning. Encyclopedia 2021, 1, 988-997. [CrossRef] 
78. Al-Rahmi, M.W.; Allias, N.; Othman, S.M.; Alzahrani, I.A.; Alfarraj, O.; Saged, A.A.; Rahman, A.H.N.A. Use of e-learning by university students in Malaysian higher educational institutions: A case in University Teknologi Malaysia. IEEE Access 2018, 6 , 14268-14276. [CrossRef]

79. Biswas, P.; Debnath, A.K. Worldwide scenario of unplanned transition to e-learning in the time of covid-19 and students' perception: A review. Mukt Shabd J. 2020, 9, 2038-2043.

80. Baber, H. Determinants of students' perceived learning outcome and satisfaction in online learning during the pandemic of COVID-19. J. Educ. E-Learn. Res. 2020, 7, 285-292. [CrossRef]

81. Zalat, M.M.; Hamed, M.S.; Bolbol, S.A. The experiences, challenges, and acceptance of e-learning as a tool for teaching during the COVID-19 pandemic among university medical staff. PLOS ONE 2021, 16, e0248758. [CrossRef]

82. Hair, J., Jr.; Sarstedt, M.; Hopkins, L.; Kuppelwieser, G.V. Partial least squares structural equation modeling (PLS-SEM) An emerging tool in business research. Eur. Bus. Rev. 2016, 26, 106-121. [CrossRef]

83. Bagozzi, R.P.; Yi, Y. On the evaluation of structural equation models. J. Acad. Mark. Sci. 1988, 16, 74-94. [CrossRef]

84. Hair, J.F.; Black, W.C.; Babin, B.J.; Anderson, R.E. Multivariate Data Analysis, 7th ed.; Prentice Hall: Hoboken, NJ, USA, 2010.

85. Chen, T.; Peng, L.; Yin, X.; Rong, J.; Yang, J.; Cong, G. Analysis of user satisfaction with online education platforms in China during the COVID-19 pandemic. Healthcare 2010, 8, 200. [CrossRef] [PubMed]

86. Kline, R.B. Principles and Practice of Structural Equation Modelling, 2nd ed.; The Guilford Press: New York, NY, USA, 2005.

87. Hwang, D.; Min, H. Identifying the drivers of enterprise resource planning and assessing its impacts on supply chain performances. Ind. Manag. Data Syst. 2015, 115, 541-569. [CrossRef]

88. Browne, M.W.; Cudeck, R. Alternative Ways of Assessing Model Fit. In Testing Structural Equation Models; Bollen, K.A., Long, J.S., Eds.; Sage: Newbury Park, CA, USA, 1993; pp. 136-162.

89. Hooper, D.; Coughlan, J.; Mullen, M.R. Structural equation modelling: Guidelines for determining model fit. J. Bus. Res. Methods. 2008, 6, 53-60.

90. Balakrishnan, N.; Barmalzan, G.; Haidari, A. Multivariate stochastic comparisons of multivariate mixture models and their applications. J. Multivar. Anal. 2016, 145, 37-43. [CrossRef]

91. Akdere, M.; Top, M.; Tekingündüz, S. Examining patient perceptions of service quality in Turkish hospitals: The SERVPERF model. Total Qual. Manag. Bus. Excell. 2020, 31, 342-352. [CrossRef]

92. Olorunniwo, F.; Hsu, M.K.; Udo, G. Service Quality, Customer Satisfaction and Behavioral Intentions in the Service Factory. J. Serv. Mark. 2006, 20, 59-72. [CrossRef]

93. Lee, B.C.; Yoon, J.O.; Lee, I. Learners' acceptance of e-learning in South Korea: Theories and results. Comput. Educ. 2009, 53, 1320-1329. [CrossRef]

94. Goh, F.C.; Leong, M.C.; Kasmin, K.; Hii, K.P.; Tan, K.O. Students' experiences, learning outcomes and satisfaction in e-learning. J. E-Learn. Knowl. Soc. 2017, 13, 117-128.

95. Mukhtar, K.; Javed, K.; Arooj, M.; Sethi, A. Advantages, Limitations and Recommendations for online learning during COVID-19 pandemic era. Pak. J. Med. Sci. 2020, 36, S27-S31. [CrossRef]

96. Gopal, R.; Singh, V.; Aggarwal, A. Impact of Online Classes on the Satisfaction and Performance of Students during the Pandemic Period of COVID 19. Educ. Inf. Technol. 2021, 26, 6923-6947. [CrossRef] [PubMed]

97. Ossiannilsson, E.; Williams, K.; Camilleri, A.F.; Brown, M. Quality Models in Online and Open Education around the Globe: State of the Art and Recommendations; International Council for Open and Distance Education: Oslo, Norway, 2015.

98. Vlachopoulos, D. Assuring Quality in E-Learning Course Design: The Roadmap. Int. Rev. Res. Open Distrib. Learn. 2016, 17, 183-205. [CrossRef] 